\title{
Plasma and Urinary Amino Acids in Children with Primary Hyperoxaluria and in Normal Children
}

\author{
DOROTHY A. GIBBS, C. J. THOMPSON*, and R. W. E. WATTS \\ From the Medical Professorial Unit, St. Bartholomew's Hospital, London
}

The demonstration of an abnormal aminoaciduria or aminoacidaemia may provide a genetic marker in the study of inherited diseases as well as help to elucidate the biochemical abnormalities that are present. The urinary excretions of oxalate and glycollate are increased in primary hyperoxaluria, and there is evidence that the metabolic lesion involves the glycine- glyoxylate pathway of glycine metabolism (Frederick, Rabkin, Richie, and Smith, 1963; Hockaday, Clayton, and Smith, 1965; Dean, Griffin, and Watts, 1966). The present investigation was undertaken to determine if patients with primary hyperoxaluria have any detectable changes in their over-all pattern of amino acid metabolism, as judged by the plasma and urinary concentrations and the renal clearances of the main physiologically important amino acids.

Except for one small series of normal prepubertal children published after this work was completed (Scriver and Davies, 1965), the available data on normal plasma and urine amino acid concentrations refer to infants and adults. We therefore studied 5 normal children to establish that there were no gross changes in the plasma and urinary amino acid levels peculiar to the age-group with which we are concerned.

\section{Methods and Subjects}

Amino acid analyses. Fasting blood and 24-hour urine samples were collected and prepared for analysis as described elsewhere (Crawhall, Thompson, and Bradley, 1966; Crawhall, Scowen, Thompson, and Watts, 1967), a Technicont amino acid analyser being used for the determinations (Crawhall et al., 1966).

Urinary oxalate was determined by isotope dilution analysis (Dean and Griffin, 1965).

Subjects. Hyperoxaluric 1, was a 12-year-old boy, height $133 \mathrm{~cm}$., weight $30.7 \mathrm{~kg}$., previously reported as

Received January 6, 1967.

* Present address: The Department of Pharmacology, School of Pharmacy (University of London), Brunswick Square, London W.C.1.

† Technicon Instruments Ltd., Chertsey, Surrey, England.
'Case 4' in 'family 4' (Hall, Scowen, and Watts, 1960). He had a right renal calculus, blood urea $32 \mathrm{mg} . / 100 \mathrm{ml}$., urinary oxalate excretion $162-319 \mathrm{mg}$. $(\mathrm{COOH})_{2} \cdot 2 \mathrm{H}_{2} \mathrm{O} /$ $24 \mathrm{hr}$., on 10 successive days.

Hyperoxaluric 2 was a girl aged 7 years, with bilateral renal calculi. Height $119 \mathrm{~cm}$., weight $22 \cdot 8 \mathrm{~kg}$., blood urea $62 \mathrm{mg} . / 100 \mathrm{ml}$., urinary oxalate excretion 121-208 mg. $(\mathrm{COOH})_{2} \cdot 2 \mathrm{H}_{2} \mathrm{O} / 24 \mathrm{hr}$., on 10 successive days. Her parents were unrelated, and one sib, who had renal calculi, died in uraemia, and oxalosis was demonstrated at necropsy.

Hyperoxaluric 3 was a 14-year-old girl, height 153 $\mathrm{cm}$., weight $46.5 \mathrm{~kg}$., referred to as 'subject 3 ' in a previous study (Crawhall and Watts, 1962). She had bilateral renal calculi, blood urea $34 \mathrm{mg} . / 100 \mathrm{ml}$., urinary oxalate excretion 154-194 mg. $(\mathrm{COOH})_{2} \cdot 2 \mathrm{H}_{2} \mathrm{O} /$ $24 \mathrm{hr}$. on successive days.

Control 1 was a 7-year-old boy, height $115.6 \mathrm{~cm}$., weight $20.9 \mathrm{~kg}$., urinary oxalate excretion $27.8 \mathrm{mg}$. $(\mathrm{COOH})_{2} \cdot 2 \mathrm{H}_{2} \mathrm{O} / 24 \mathrm{hr}$. He was studied immediately before being discharged from hospital after an attack of acute encephalitis.

Control 2 was a 9-year-old boy, height $139 \cdot 7 \mathrm{~cm}$., weight $31.8 \mathrm{~kg}$., urinary oxalate excretion $39.5 \mathrm{mg}$. $(\mathrm{COOH})_{2} \cdot 2 \mathrm{H}_{2} \mathrm{O} / 24 \mathrm{hr}$.

Control 3 was an 8-year-old girl, height $129.5 \mathrm{~cm}$., weight $27.9 \mathrm{~kg}$., urinary oxalate excretion $29.4 \mathrm{mg}$. $(\mathrm{COOH})_{2} \cdot 2 \mathrm{H}_{2} \mathrm{O} / 24 \mathrm{hr}$.

Control 4 was a 7-year-old girl height $121 \mathrm{~cm}$., weight $20 \cdot 6 \mathrm{~kg}$., urinary oxalate excretion $22-30 \mathrm{mg}$. $(\mathrm{COOH})_{2}$. $2 \mathrm{H}_{2} \mathrm{O} / 24 \mathrm{hr}$. on 6 successive days.

Control 5 was an 8-year-old girl, height $125 \mathrm{~cm}$., weight $19.6 \mathrm{~kg}$., urinary oxalate excretion $23-30 \mathrm{mg}$. $(\mathrm{COOH})_{2} \cdot 2 \mathrm{H}_{2} \mathrm{O} / 24 \mathrm{hr}$. on 6 successive days. All the control subjects were free from evidence of metabolic, endocrine, or renal disease.

\section{Results}

The 24-hour amino acid excretions, plasma amino acid concentrations, and 24-hour renal clearances of amino acids were the same in the hyperoxaluric and control subjects (Tables $I$ and II). No abnormal ninhydrin reacting substances were detected in any of the plasma and urine samples. Similar amounts of ethanolamine were present in some specimens from both the hyper- 
TABLE I

Urinary Excretion and Plasma Concentration of Amino Acids in Patients with Primary Hyperoxaluria and in Non-hyperoxaluric Controls

\begin{tabular}{|c|c|c|c|c|c|c|c|c|c|c|c|c|}
\hline \multirow{3}{*}{ Amino Acid } & \multicolumn{6}{|c|}{$\begin{array}{c}\text { Urine } \\
(\mu \mathrm{mole} / \mathrm{min} .1 \cdot 73 \text { sq. m. })\end{array}$} & \multicolumn{6}{|c|}{$\begin{array}{c}\text { Plasma } \\
\left(\mu \mathrm{mole} / \mathrm{ml}_{\bullet}\right)\end{array}$} \\
\hline & \multicolumn{4}{|c|}{ Primary Hyperoxaluria Patients } & \multicolumn{2}{|r|}{ Controls } & \multicolumn{4}{|c|}{ Primary Hyperoxaluria Patients } & \multicolumn{2}{|r|}{ Controls } \\
\hline & 1 & & & 3 & Mean & Extreme Range & 1 & & & 3 & Mean & Extreme Range \\
\hline 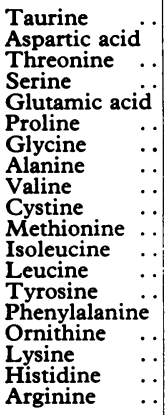 & $\begin{array}{l}\bar{Z} \\
0 \cdot \overline{214} \\
0 \cdot 366 \\
0 \cdot 109 \\
0 . \overline{981} \\
0 \cdot \overline{261} \\
0 \cdot \overline{058} \\
\overline{-} \\
0 \cdot \overline{055} \\
0 \cdot 138 \\
0 \cdot 065 \\
0 \cdot 120 \\
1 \cdot \overline{144} \\
-\end{array}$ & $\begin{array}{l}0.957 \\
0.087 \\
0.066 \\
0.323 \\
0.047 \\
0 . \overline{758} \\
0.225 \\
0.041 \\
0.042 \\
= \\
0 . \overline{035} \\
0.074 \\
0.078 \\
0 . \overline{158} \\
0.480 \\
-\end{array}$ & $\begin{array}{c}\bar{Z} \\
0 . \overline{214} \\
0.053 \\
\overline{0} \\
0 . \overline{329} \\
0.139 \\
0.019 \\
0.026 \\
\bar{Z} \\
0 . \overline{046} \\
0.047 \\
0.065 \\
0 . \overline{351} \\
0.242 \\
-\end{array}$ & $\begin{array}{l}0.097 \\
0.058 \\
0.267 \\
0 . \overline{059} \\
0 . \overline{719} \\
0.307 \\
0 . \overline{027} \\
= \\
\bar{Z} \\
0 . \overline{035} \\
0.036 \\
0.027 \\
0.172 \\
0.182 \\
-\end{array}$ & $\begin{array}{l}0 \cdot 598 \\
0 \cdot 170 \\
0 \cdot 152 \\
0 \cdot 309 \\
0 \cdot 113 \\
1 \cdot \overline{46} \\
0 \cdot 240 \\
0 \cdot 049 \\
0 \cdot 030 \\
0 \cdot 042 \ddagger \\
0 \cdot 030 \\
0 \cdot 056 \\
0 \cdot 104 \\
0 \cdot 071 \\
0.316 \\
0.536 \\
0.555 \\
0.046 \ddagger\end{array}$ & $\begin{array}{l}0.147-0.952(5) \dagger \\
0.046-0.295(5) \\
0.078-0.306(4) \\
0.166-0.585(4) \\
0.086-0.164(3) \\
0.459-2.60(5) \\
0.147-0.426(5) \\
0.042-0.055(2) \\
0.024-0.034(3) \\
0.022-0.037(2) \\
0.048-0.068(3) \\
0.063-0.197(4) \\
0.015-0.132(3) \\
0 . \\
0.358-0.629(4) \\
0.085-1.600(4) \\
-\end{array}$ & $\begin{array}{l}0.036 \\
0.031 \\
0.076 \\
0.061 \\
0 . \overline{250} \\
0.200 \\
0.370 \\
0 . \overline{031} \\
0.019 \\
0.070 \\
0.170 \\
0.082 \\
0.053 \\
0.058 \\
0.200 \\
0.084 \\
0.098\end{array}$ & $\begin{array}{l}0.036 \\
0.013 \\
0.104 \\
0.053 \\
0.077 \\
0 . \overline{200} \\
0.224 \\
0.168 \\
0.022 \\
0.015 \\
0.049 \\
0.094 \\
0.046 \\
0.049 \\
0.043 \\
0.123 \\
0.090 \\
0.072\end{array}$ & $\begin{array}{l}0 \cdot 181 \\
0.014 \\
0.070 \\
0.095 \\
0 \cdot 177 \\
0.218 \\
0 \cdot 215 \\
0.184 \\
0.059 \\
0.014 \\
0.043 \\
0.095 \\
0.039 \\
0.046 \\
0.060 \\
0.121 \\
0.064 \\
0.042\end{array}$ & $\begin{array}{l}0.031 \\
0.009 \\
0.013 \\
0.120 \\
0.074 \\
0 . \overline{280} \\
0.360 \\
0.150 \\
0.046 \\
0.037 \\
0.049 \\
0.079 \\
0.059 \\
0.062 \\
0.042 \\
0.125 \\
0.078 \\
0.084\end{array}$ & 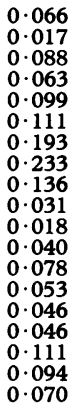 & 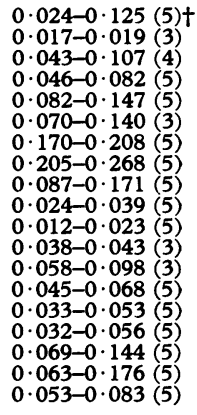 \\
\hline
\end{tabular}

* Duplicate values shown for hyperoxaluric Patient 2 were obtained on separate 24-hour urine collections and blood samples.

+ Number of observations on which the mean and extreme range are based.

¥ Single value.

A dash - indicates the amino acid concerned was either absent or if present the peak on the amino acid tracing was too small to be integrated accurately.

oxaluric and control patients, but we were unable to study this compound quantitatively.

\section{Discussion}

The present values for the plasma concentration and urinary excretion of the amino acids have been expressed as $\mu \mathrm{mole} / \mathrm{ml}$. and as $\mu \mathrm{mole} / \mathrm{min} .1 \cdot 73$ sq.m. body surface area, in order to facilitate the comparison of our results with those of the other workers (Scriver and Davis, 1965), who have studied normal older children as opposed to infants or adults. The results for Patient 3 who was 14 years

TABLE II

24-hour Renal Clearances of Amino Acids in Patients with Primary Hyperoxaluria and in Non-hyperoxaluric Controls

\begin{tabular}{|c|c|c|c|c|c|c|c|c|c|c|c|}
\hline \multirow{3}{*}{\multicolumn{3}{|c|}{ Amino Acid }} & \multicolumn{9}{|c|}{$\begin{array}{c}\text { Renal Clearance } \\
\text { (ml./min. } 1 \cdot 73 \text { sq. } \mathrm{m} . \text { ) }\end{array}$} \\
\hline & & & \multicolumn{4}{|c|}{ Patients with Primary Hyperoxaluria } & \multicolumn{5}{|c|}{ Non-hyperoxaluric Subjects } \\
\hline & & & 1 & & & 3 & 1 & 2 & 3 & 4 & 5 \\
\hline $\begin{array}{lc}\text { Taurine } & \ldots \\
\text { Aspartic acid } & \ldots \\
\text { Threonine } & \ldots \\
\text { Serine . } & \ldots \\
\text { Glutamic acid } & \text {. } \\
\text { Glycine } & \ldots \\
\text { Alanine } & \ldots \\
\text { Valine .. } & \ldots \\
\text { Cystine } & \ldots \\
\text { Methionine } & \ldots \\
\text { Isoleucine } & \ldots \\
\text { Leucine } & \ldots \\
\text { Tyrosine } & \ldots \\
\text { Phenylalanine.. } \\
\text { Ornithine } & \ldots \\
\text { Lysine.. } & \ldots \\
\text { Histidine } & \ldots \\
\text { Arginine } & \ldots\end{array}$ & $\begin{array}{l}\cdots \\
\cdots \\
\cdots \\
\cdots \\
\cdots \\
\cdots \\
\cdots \\
\cdots \\
\cdots \\
\cdots \\
\cdots \\
\cdots \\
\cdots \\
\cdots\end{array}$ & $\begin{array}{l}\ldots \\
\cdots \\
. \\
\cdots \\
\cdots \\
\cdots \\
\cdots \\
. \\
\cdots \\
\cdots \\
\cdots \\
\cdots \\
\cdots \\
\cdots \\
\cdots\end{array}$ & $\begin{array}{l}\overline{-} \\
\overline{2 \cdot 82} \\
6 \cdot 05 \\
\overline{4} \\
0 \cdot 93 \\
\overline{0} \cdot 70 \\
1 \cdot 88 \\
\overline{-} \\
0 \cdot 31 \\
1 \cdot 68 \\
1 \cdot 24 \\
2 \cdot 06 \\
\overline{13 \cdot 68} \\
-\end{array}$ & $\begin{array}{l}\overline{6 \cdot 09} \\
\overline{3 \cdot 06} \\
0 \cdot 56 \\
1 \cdot 52 \\
0 \cdot 65 \\
0 \cdot 10 \\
0 \cdot 46 \\
0.87 \\
0.50 \\
1 \cdot 21 \\
1 \cdot 39 \\
2.89 \\
3 \cdot 79 \\
-\end{array}$ & $\begin{array}{l}26 \cdot 64 \\
-\overline{1} \\
6 \cdot 14 \\
0 \cdot 60 \\
3 \cdot 72 \\
0 \cdot 94 \\
0 \cdot 25 \\
1 \cdot 85 \\
0 \cdot 19 \\
0 \cdot 37 \\
1 \cdot 62 \\
1 \cdot 56 \\
1.29 \\
5 \cdot 35 \\
-\end{array}$ & $\begin{array}{l}3 \cdot 18 \\
6 \cdot 15 \\
1 \cdot 99 \\
\overline{0 \cdot 79} \\
2 \cdot 52 \\
0 \cdot 84 \\
\overline{-} \\
0.59 \\
- \\
- \\
3 \cdot 27 \\
3 \cdot 53 \\
0.65 \\
1.37 \\
2 \cdot 33 \\
-\end{array}$ & $\begin{array}{l}9 \cdot 08 \\
9 \cdot 01 \\
\overline{3} \cdot 31 \\
0 \cdot 90 \\
2 \cdot 29 \\
0 \cdot 56 \\
= \\
= \\
= \\
1 \cdot 30 \\
1 \cdot 22 \\
\overline{5} \cdot 15 \\
6 \cdot 47 \\
-\end{array}$ & $\begin{array}{c}7 \cdot 62 \\
17 \cdot 77 \\
2 \cdot 85 \\
7 \cdot 13 \\
1 \cdot 88 \\
4 \cdot 73 \\
2 \cdot 00 \\
-\overline{0} \cdot 81 \\
2 \cdot 27 \\
0 \cdot 97 \\
0 \cdot 81 \\
2 \cdot 89 \\
2 \cdot 52 \\
- \\
17 \cdot 58 \\
-\end{array}$ & $\begin{array}{l}9 \cdot 77 \\
7 \cdot 25 \\
1 \cdot 12 \\
2 \cdot 01 \\
0 \cdot 59 \\
8 \cdot 93 \\
1 \cdot 07 \\
0 \cdot 26 \\
0 \cdot 78 \\
-\overline{0} \cdot 55 \\
0 \cdot 67 \\
1 \cdot 47 \\
0 \cdot 40 \\
6 \cdot 85 \\
4 \cdot 88 \\
0 \cdot 35 \\
0 \cdot 78\end{array}$ & 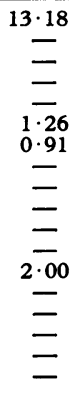 & $\begin{array}{l}6 \cdot 14 \\
\overline{0} \cdot 76 \\
0 \cdot 72 \\
\overline{-} \\
0 \cdot 89 \\
0 \cdot 78 \\
0 \cdot 68 \\
1 \cdot 42 \\
= \\
= \\
- \\
- \\
7 \cdot 00 \\
1 \cdot 11 \\
-\end{array}$ \\
\hline
\end{tabular}

\footnotetext{
* Duplicate values shown for hyperoxaluric Subject 2 were obtained in separate 24-hour clearance studies.
} 
old are in general agreement with the younger members of the series, and the present data for 24-hour clearances agree with the findings of Scriver and Davies (1965) who used 3-hour clearance periods following an overnight fast. Age appears to have little effect on the plasma and urinary amino acid levels, the published values for infants and young children (e.g. O'Brien and Butterfield, 1963; Ghadimi and Pecora, 1964; Cockburn, Sherman, Ingall, and Klein, 1965; Dickinson, Rosenblum, and Hamilton, 1965), and for adults (e.g. Stein and Moore, 1954; Evered, 1956; Cusworth and Dent, 1960; Ackerman and Kheim, 1964; Iob, McMath, and Coon, 1963; Wehr and Lewis, 1966) being in general agreement with the present values.

Frederick et al. (1963) and Hockaday et al. (1965) reported decreased metabolism of glyoxylate to glycine and carbon dioxide in patients with primary hyperoxaluria, as judged by reduced incorporation of $\left[1-{ }^{14} \mathrm{C}\right]$ glyoxylate into the urinary glycine and hippurate, and into respiratory carbon dioxide. Dean et al. (1966) found that glycine and carbon dioxide formation, from glyoxylate $-\mathrm{C}_{1}$, were grossly impaired in kidney tissue from two cases of primary hyperoxaluria. However, the hepatic metabolism of glyoxylate appears to be normal in the disease (Crawhall and Watts, 1962; Hockaday et al., 1965; Dean, Watts, and Westwick, 1967). The metabolic abnormality in primary hyperoxaluria is not reflected in the plasma concentration or renal excretion of glycine or of the other amino acids (Tables I and II), indicating either that the transaminase system, which is defective in the disease, is unimportant from the point of view of glycine homeostasis, or that reduced activity of the pathway can be compensated by increased glycine synthesis. Ethanolamine is a possible precursor of glycine via glyoxylate (Arnstein, 1954), and it is of interest that the defective glyoxylate metabolism in primary hyperoxaluria does not lead to a gross accumulation of this substance.

The inborn metabolic errors in which there is a major defect in intermediary amino acid metabolism with overt changes in the concentrations of amino acids and their metabolites in the body fluids are often associated with gross clinical abnormalities. The absence of any detectable abnormality in the pattern of amino acid composition of the blood and urine in the present study is in accord with the clinical observation that children with primary hyperoxaluria develop normally and remain asymptomatic until urinary lithiasis and nephrocalcinosis occur.

\section{Summary}

The 24-hour excretions of amino acids, the plasma amino acid concentrations, and the renal clearances of the amino acids were studied by ion exchange chromatography in a group of children with primary hyperoxaluria and in control children of similar ages. There were no significant differences between the two groups. The results are discussed in relation to the published data on the amino acid concentrations in blood and urine in normal subjects, and to the current views concerning the aetiology of the disease.

We are pleased to acknowledge our indebtedness to Professor E. F. Scowen for his continued interest and encouragement in these studies, to Dr. N. R. Butler and Dr. O. Wrong who referred patients to one of us (R. W. E. Watts) for study, to Dr. E. G. Hall who arranged the collection of specimens of blood and urine from hyperoxaluric Patient 1 for us, to Mr. P. Woodward and Mr. D. Chapman for their help with some of the analyses, and to the Governors of St. Bartholomew's Hospital for their generous research grants.

\section{REFFRENCES}

Ackerman, P. G., and Kheim, T. (1964). Plasma amino acids in young and older adult human subjects. Clin. Chem., 10, 32.

Arnstein, H. R. V. (1954). The metabolism of glycine. Advanc. Protein Chem., 9, 1.

Cockburn, F., Sherman, J. D., Ingall, D., and Klein, R. (1965). Effect of phenylalanine deficient diet on bone marrow and amino acid metabolism. Proc. Soc. exp. Biol. (N.Y.), 118, 238.

Crawhall, J. C., Scowen, E. F., Thompson, C. J., and Watts, R. W. E. (1967). The renal clearance of amino acids in cystinuria. f. clin. Invest., 46, 1162.

—, Thompson, C. J., and Bradley, K. H. (1966). Separation of cystine, penicillamine disulfide and cysteine-penicillamine mixed disulfide by automatic amino acid analysis. Analyt. Biochem., 14, 405.

- and Watts, R. W. E. (1962). The metabolism of $\left[1-{ }^{14} \mathrm{C}\right]$ glyoxylate by the liver mitochondria of patients with primary hyperoxaluria and non-hyperoxaluric subjects. Clin. Sci., 23, 163.

Cusworth, D. C., and Dent, C. E. (1960). Renal clearances of amino acids in normal adults and in patients with aminoaciduria. Biochem. F., 74, 550.

Dean, B. M., and Griffin, W. J. (1965). Estimation of urinary oxalate by the method of isotope dilution. Nature (Lond.), 205, 598.

, - and Watts, R. W. E. (1966). Primary hyperoxaluria. The demonstration of a metabolic abnormality in kidney tissue. Lancet, 1, 406.

-, Watts, R. W. E., and Westwick, W. J. (1967). Metabolism of $\left[1-{ }^{14} \mathrm{C}\right]$ glyoxylate, $\left[1-{ }^{14} \mathrm{C}\right]$ glycollate, $\left[1-{ }^{14} \mathrm{C}\right]$ glycine and $\left[2-{ }^{14} \mathrm{C}\right]$ glycine by homogenates of kidney and liver tissue from hyperoxaluric and control subjects. Biochem. $\mathcal{F}$. In the press.

Dickinson, J. C., Rosenblum, H., and Hamilton, P. B. (1965). Ion exchange chromatography of the free amino acids in the plasma of the newborn infant. Pediatrics, 36, 2.

Evered, D. F. (1956). The excretion of amino acids by the human. A quantitative study with ion-exchange chromatography. Biochem. F., 62, 416.

Frederick, E. W., Rabkin, M. T., Richie, R. H., and Smith, L. H. (1963). Studies on primary hyperoxaluria. 1. In vivo demonstration of a defect in glyoxylate metabolism. New Engl. f. Med., 269, 821. 
Ghadimi, H., and Pecora, P. (1964). Plasma amino acids after birth. Pediatrics, 34, 182.

Hall, E. G., Scowen, E. F., and Watts, R. W. E. (1960). Clinical manifestations of primary hyperoxaluria. Arch. Dis. Childh., 35, 108.

Hockaday, T. D. R., Clayton, J. E., and Smith, L. H., Jr. (1965). The metabolic error in primary hyperoxaluria. ibid., 40, 485.

Iob, V., McMath, M., and Coon, W. W. (1963). Intra-individual and inter-individual variations in plasma free amino acids in normal adults. f. surg. Res., 3, 85 .
O'Brien, D., and Butterfield, L. J. (1963). Further studies on renal tubular conservation of free amino acids in early infancy. Arch. Dis. Childh., 38, 437.

Scriver, C. R., and Davies, E. (1965). Endogenous renal clearance rates of free amino acids in prepubertal children. Pediatrics, $36,592$.

Stein, W. H., and Moore, S. (1954). The free amino acids of human blood plasma. F. biol. Chem., 211, 915.

Wehr, R. F., and Lewis, G. T. (1966). Amino acids in blood plasma of young and aged adults. Proc. Soc. exp. Biol. (N.Y.), 121, 349. 